\title{
Experimental infection of the echinoid Strongylocentrotus droebachiensis with Paramoeba invadens: quantitative changes in the coelomic fluid
}

\author{
Joanne F. Jellett, Alastair C. Wardlaw*, Robert E. Scheibling \\ Biology Department, Dalhousie University, Halifax, Nova Scotia, Canada B3H 4J1
}

\begin{abstract}
Paramoebiasis, due to Paramoeba invadens, was transmitted from diseased to healthy echinolds Strongylocentrotus droebachiensis in the waterborne infection apparatus of Scheibling \& Stephenson (1984). Control echinoids were exposed to healthy S. droebachiensis in a parallel apparatus. Groups of 8 individuals from the infected treatment were sacrificed in the pre-symptomatic period and at 24 and $72 \mathrm{~h}$ after development of symptoms of the disease, as evidenced by loss of attachment (LOA) to aquarium surfaces. Groups of 8 individuals from the control treatment were removed and sampled at the same time. Coelomic fluid (CF) was drawn into EGTA as an anticoagulant, and the concentration of coelomocytes determined directly and after density-gradient fractionation into 3 different cell bands. The concentration of total coelomocytes was significantly lower in infected echinoids than in controls, due to smaller numbers of cells in the band containing white spherule and vibratile cells and that containing red spherule cells. The concentration of phagocytes did not differ significantly between the infected and control groups. Protein concentration in cell-free CF of infected echinoids at $72 \mathrm{~h}$ post-LOA (mean $\left.\pm \mathrm{SE}=446.25 \pm 51.69 \mu \mathrm{g} \mathrm{ml}{ }^{-1}\right)$ was about twice that of control individuals $(238.56 \pm 16.60$

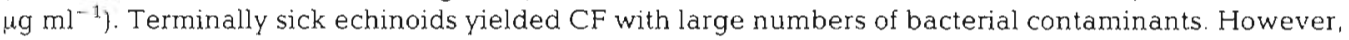
in vitro bactericidal activity of the fluid towards a reference marine pseudomonad did not change significantly during progression of paramoebiasis. Membrane-filtered coelomic fluid with elevated protein values from moribund, infected individuals was injected into healthy echinoids for toxin detection, but no disease symptoms appeared. Subsequent exposure of these individuals to waterborne $P$. invadens resulted in the usual course of disease. While pathogenesis of paramoebiasis remains obscure, possible mechanisms include activation of autolysis in the echinoid or production of degradative enzymes by the amoeba.
\end{abstract}

\section{INTRODUCTION}

Mass mortalities of the echinoids Strongylocentrotus droebachiensis occurred along the Atlantic coast of Nova Scotia, Canada, between 1980 and 1983 (Miller \& Colodey 1983, Scheibling \& Stephenson 1984) with a resulting major impact on the ecology of this area (Scheibling 1984, 1986, Miller 1985). The etiological agent was identified as the marine amoeba Paramoeba invadens Jones, 1985 by its recovery from the tissues of diseased echinoids (Jones \& Scheibling 1985, Jones et al. 1985), by experimental transmission by injection

\footnotetext{
- Present address: Department of Microbiology, University of Glasgow, Glasgow G11 6NU, Scotland, UK
}

(Jones \& Scheibling 1985) and by exposure to water containing diseased individuals (Scheibling \& Stephenson 1984, Jones \& Scheibling 1985). In addition, $P$. invadens could be re-isolated from diseased but not from healthy echinoids (Jones \& Scheibling 1985). An association between transmission and progression of disease and environmental temperature was established through field observations and by laboratory experiments (Scheibling \& Stephenson 1984). A method of monoxenic culture of Paramoeba invadens has been developed and used to demonstrate a similar relationship between temperature and growth rate of the amoebae in vitro (Jellett 1988).

A salient feature of echinoid paramoebiasis is the onset of symptoms about $10 \mathrm{~d}$ after initial exposure. 
The first manifestation is loss of attachment (LOA) of the echinoid to the substratum (Scheibling \& Stephenson 1984, Jones et al. 1985) and failure to right itself after being inverted. This disability is associated with muscular degeneration, as seen histologically (Jones et al. 1985), and is accompanied by drooping and progressive loss of spines, gaping of the mouth and jaws, and reddish-brown discoloration of most tissues. Paramoeba invadens is widespread in the tissues of infected echinoids but generally occurs at low density (Jones et al. 1985). It can be consistently isolated by culture of the radial nerves and associated water vascular tissue from symptomatic individuals (Jones \& Scheibling 1985). Bacterial infection has been reported in late stage paramoebiasis although bacteria are believed to be secondary invaders in moribund individuals (Jones \& Scheibling 1985)

In this study, pathophysiological changes in the coelomic fluid of Strongylocentrotus droebachiensis were examined during experimental infection with Paramoeba invadens by quantitative monitoring of the coelomocytes, soluble protein, in vitro bactericidal activity and bacterial contamination during the course of the disease. Some possible modes of action of $P$. invadens in echinoid paramoebiasis are discussed in the light of the results obtained.

\section{MATERIALS AND METHODS}

Echinoids. Adult Strongylocentrotus droebachiensis (52 to $75 \mathrm{~mm}$ horizontal test diameter) were collected at Sandy Cove, Nova Scotia, Canada $\left(44^{\circ} 30^{\prime} \mathrm{N}\right.$, $66^{\circ} 07^{\prime} \mathrm{W}$ ). They were held in a flow-through seawater system at ambient sea temperature $\left(12\right.$ to $\left.15^{\circ} \mathrm{C}\right)$ and fed kelp (Laminaria). One wk prior to the experiment, feeding was stopped and the echinoids were acclimated at a rate of $2 \mathrm{C}^{\circ}$ per day to the experimental temperature, $16^{\circ} \mathrm{C} \pm 1{ }^{\circ} \mathrm{C}$, chosen because it falls within the range observed at the time of the natural epizootic (Scheibling 1984). Healthy echinoids were experimentally infected with Paramoeba invadens after the method of Scheibling \& Stephenson (1984). Two groups of echinoids $(n=27$ and 32 for infection and control treatments respectively) were placed in separate $47 \mathrm{l}$ glass aquaria and exposed continuously to water flowing (approximately $1 \mathrm{l} \mathrm{min}^{-1}$ ) past 5 infected or 5 healthy (control) echinoids in separate 21 clear plexiglass tubes $(8 \mathrm{~cm}$ diameter) that were spliced into the incurrent seawater lines of the respective aquaria. Infected echinoids (the source of $P$. invadens) were obtained from laboratory infection tanks which have been maintained continuously since October 1982 (for details, see Scheibling \& Stephenson 1984). Infected echinoids were replaced every 2 to $3 \mathrm{~d}$ so that only individuals exhibiting initial symptoms of paramoebiasis were used. Eight echinoids from each treatment were sampled randomly at $6 \mathrm{~d}$ from the onset of exposure to $P$. invadens (pre-symptomatic), and at 24 and $72 \mathrm{~h}$ after loss of attachment (LOA) in the infection group

Culturing for Paramoeba invadens. Following the extraction of coelomic fluid samples (see below), each echinoid was dissected and the gross external and internal morphology was recorded. A portion of each of the 5 radial nerves (with associated water vascular canal) was removed and cultured at $15^{\circ} \mathrm{C}$ for $P$. invadens on artificial seawater (ASW $=3.6 \% \mathrm{~W} / \mathrm{v}$ RILA Marine Salts, Rila Products Ltd, PO Box 114, Teaneck, NJ, USA) with $0.6 \%$ non-nutrient agar (Jellett 1988). Each tissue sample was montored for emerginy amoebae for up to $30 \mathrm{~d}$. The radial nerve/water vascular canal tissue represents a consistent source of $P$. invadens in infected echinoids (Jones \& Scheibling 1985, Jellett 1988).

Removal of coelomic fluid. The peristomal membrane of the echinoid was cleansed and then rinsed with sterile ASW. The peristome was punctured towards its outer margin (after Wardlaw \& Messer 1982) with a sterile 21 -gauge $2.5 \mathrm{~cm}$ needle mounted on a $5.0 \mathrm{ml}$ plastic disposable syringe.

Two separate samples of coelomic fluid were withdrawn from each echinoid. First, a $2 \mathrm{ml}$ sample was withdrawn into $3 \mathrm{ml}$ of pre-chilled anticoagulant. The anticoagulant (H\&S) was modified from Henson \& Schatten (1983) and consisted of $0.42 \mathrm{M} \mathrm{NaCl}, 0.03 \mathrm{M}$ EGTA [ethylene glycol bis( $\beta$-aminoethyl ether) tetraacetic acid], $0.026 \mathrm{MKCl}$, and $0.01 \mathrm{M}$ Tris- $\mathrm{HCl}$ adjusted to $\mathrm{pH} 7.6$ with $2 \mathrm{NNaOH}$. The $\mathrm{H} \& \mathrm{~S}$ was adjusted to be approximately isotonic ( $865 \mathrm{mOsm} \mathrm{kg}^{-1}$ ) with coelomic fluid as determined by osmometry. Two ml. of the coelomic fluid in $\mathrm{H} \& \mathrm{~S}$ were used for density-gradient centrifugation, and the remainding $3 \mathrm{ml}$ were chilled on ice and a subsample counted for total coelomocytes. A second sample of 4 to $5 \mathrm{ml}$ of coelomic fluid was withdrawn immediately after the first into a pre-chilled syringe without anticoagulant. 'Two ml were then used for the bactericidal tests, $0.1 \mathrm{ml}$ to monitor bacterial contamination and the remainder was centrifuged for 10 min at $200 \times \mathrm{g}$ at $4{ }^{\circ} \mathrm{C}$ in a Beckman Clinical centrifuge Model TJ-R. The supernate was separated and frozen for protein analysis and toxicity tests.

Density-gradient centrifugation. A $2.0 \mathrm{mI}$ sample of coelomic fluid in $\mathrm{H} \& \mathrm{~S}$ anticoagulant $(3: 2)$ was layered on top of a discontinuous gradient of sodium metrizoate (Fig. 1A) modified from Bertheussen \& Seljelid (1978). Gradients were made in Beckman Ultra-Clear $14 \times 89$ $\mathrm{mm}$ centrifuge tubes and cooled at $5^{\circ} \mathrm{C}$ prior to use. The cushion fluid $(2.0 \mathrm{ml})$ was $34.3 \%(\mathrm{w} / \mathrm{v})$ sodium metrizoate (Sigma) in distilled water, which was 
Fig. 1 Density-gradient separation of coelomocytes. (A) Discontinuous gradient of sodium metrizoate; sample is $2 \mathrm{ml}$ taken from a mixture of $3 \mathrm{ml} \mathrm{H} \& S$ anticoagulant and $2 \mathrm{ml}$ coelomic fluid. (B) Separation of different coelomocyte types after centrifugation in the density gradient; Band Region 1 contains mainly phagocytes, Region 2 has mainly white spherule cells and vibratiles, Region 3 contains mainly red spherule cells. (C) Fractions taken for counting

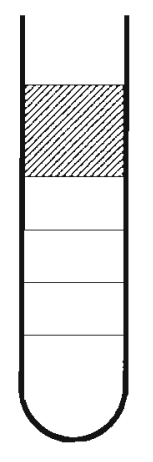

A

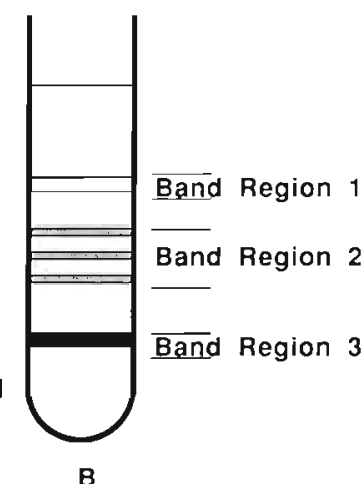

B

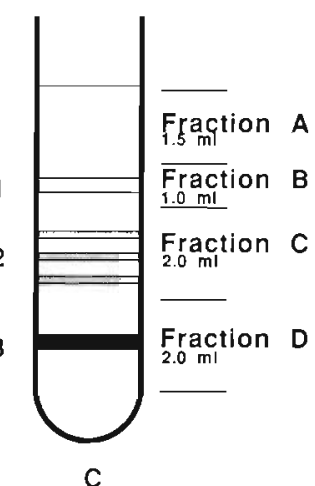

c isotonic with the coelomic fluid and had a $\mathrm{pH}$ of 7.6. To make the gradient, the cushion fluid was diluted to 70 , 50 and $30 \%(\mathrm{v} / \mathrm{v})$ with isotonic $\mathrm{H} \& \mathrm{~S}$ anticoagulant, yielding Layers 1, 2 and 3 respectively (Fig. 1A), which were pipetted on top of the cushion fluid in volumes of $1.0 \mathrm{ml}$ each. The $\mathrm{pH}$ of the sodium metrizoate gradient was constant at $\mathrm{pH} 7.6$ and did not change when the sample was added.

Care was taken not to expose coelomocytes to osmotic shock. The tonicity of all fluids used in the manipulation of the cells was within $3 \%$ of the measured tonicity of the coelomic fluid which had a mean osmolality of $872 \mathrm{mOsm} \mathrm{kg} \mathrm{k}^{-1}$ (range 869 to 877 ). RILA at $3.6 \% \mathrm{w} / \mathrm{v}$ was $875 \mathrm{mOsm} \mathrm{kg}{ }^{-1}$. H\&S anticoagulant measured $865 \mathrm{mOsm} \mathrm{kg}{ }^{-1}$, and the cushion fluid of the density gradient $851 \mathrm{mOsm} \mathrm{kg}{ }^{-1}$.

Counting of coelomocytes. Coelomocytes were counted in a Coulter Counter Model TAII with an aperture diameter of $140 \mu \mathrm{m}$. The electrolyte was $150 \mathrm{ml}$ fresh unfiltered seawater. Two background counts of the electrolyte were recorded and then a $0.1 \mathrm{ml}$ sample of the unfractionated coelomic fluid in $\mathrm{H} \& \mathrm{~S}$ anticoagulant or a $0.2 \mathrm{ml}$ sample of a density gradient fraction were added and allowed to stir for $1 \mathrm{~min}$. Duplicate counts were recorded directly from Channels 2 to 15 for each sample and stored in a MacIntosh microcomputer. The actual number of particles per $\mathrm{ml}$ in each channel was calculated. Coelomocytes were found in Channels 7 to 11 only (the total count of cells per ml for each fraction was obtained by first adding the counts in these 5 channels).

Protein concentration in coelomic fluid supernates. Samples of coelomic fluid supernates were thawed and portions were spun for $5 \mathrm{~min}$ at $850 \times g$ at $4{ }^{\circ} \mathrm{C}$. Protein in spun supernates was measured by a modification of the microprotein phenol reagent method for biological fluids (Sigma procedure No. 690) with the sample and reagent amounts halved. Subsamples of the spun supernates were removed and treated first with biuret reagent, whereupon a precipitate, presumed to be cal- cium carbonate, was pelleted by centrifugation for $5 \mathrm{~min}$ at $850 \times \mathrm{g}$ at $4^{\circ} \mathrm{C}$. This supernate was then removed and Folin reagent added to the required portion. After colour development for $30 \mathrm{~min}$ at room temperature, samples were read at $725 \mathrm{~nm}$ in a $0.5 \mathrm{ml}$ quartz precision optical cuvette in a Varian DMS 90 UV/Visible Spectophotometer. Duplicate samples of coelomic fluid from each echinoid were analysed for protein and duplicate readings were averaged for each sample. Standard curves were prepared with bovine serum albumin (Sigma) diluted with ASW and processed in the same way as cell-free coelomic fluid.

Toxicity of membrane-filtered coelomic fluid. Portions of four $72 \mathrm{~h}$ post-LOA and 4 control cell-free coelomic fluid supernates were thawed and spun for 5 min at $850 \times g$ at $4^{\circ} \mathrm{C}$. The supernates of each treatment were removed, pooled and filtered through a lowprotein-binding $0.2 \mu \mathrm{m}$ Millipore GA filter. One $\mathrm{ml}$ of the filtrate was then injected into healthy echinoids, with 12 individuals receiving experimental filtrate and 12 receiving control filtrate. Two experimental and 2 control groups $(n=6)$ were maintained in aquaria at $16 \pm 1{ }^{\circ} \mathrm{C}$ and were monitored daily for symptoms of paramoebiasis. After $30 \mathrm{~d}$, each group was continually exposed to 5 diseased echinoids in the waterborne infection apparatus described above and monitored daily for $15 \mathrm{~d}$.

Media and reagents for bacterial culture. LIB-X marine agar medium was prepared by adding $1.2 \%$ (w/v) agar to LIB-X marine broth (Baross et al. 1974) and was dispensed in slants in screw-capped tubes and in $100 \mathrm{~mm}$ Petri dishes. Bacterial suspensions were prepared and diluted in filter-sterilized ASW to which had been added $2 \%(\mathrm{v} / \mathrm{v})$ LIB-X Marine Broth. This diluent was designated SWLX (Seawater-LIB-X).

Bacterial suspension. Pseudomonas strain No. 111 (Wardlaw \& Unkles 1978) was cultured for $2 \mathrm{~d}$ at $20^{\circ} \mathrm{C}$ on a slant of LIB-X marine agar and harvested in $2 \mathrm{ml}$ SWLX. With SWLX as diluent, the bacterial suspension was adjusted to optical density $(O D)=0.3$ at $540 \mathrm{~nm}$ in 
a $12 \mathrm{~mm}$ diameter tube in a Spectronic 20 colorimeter This suspension had a viable count of approximately $3 \times 10^{8}$ colony-forming units per $\mathrm{ml}\left(\mathrm{CFU} \mathrm{ml} \mathrm{m}^{-1}\right.$ ) and was diluted $1: 3750$ to give a suspension containing approximately $8 \times 10^{4} \mathrm{CFU} \mathrm{ml^{-1 }}$ for use in the bactericidal tests.

Bactericidal titer of coelomic fluid. A semi-quantitative procedure for titrating the bactericidal activity of coelomic fluid was as follows: within a few seconds of withdrawal of the fluid (without $\mathrm{H} \& \mathrm{~S}$ anticoagulant) from the echinoid, $0.975 \mathrm{ml}$ portions were delivered directly from the syringe to two $16 \times 100 \mathrm{~mm}$ sterile capped tubes held in an ice bath. The first tube was empty. The second tube contained $0.975 \mathrm{mI}$ SWLX and therefore diluted the rnelomic fluid $1: 2$. After mixing the contents of the second tube, $0.975 \mathrm{ml}$ was transferred with a $1.0 \mathrm{ml}$ pipette to $0.975 \mathrm{ml}$ SWLX in a third tube to give a $1: 4$ dilution. This process was continued to give $1: 8$ and $1: 16$ dilutions, $0.975 \mathrm{ml}$ finally being discarded from the latter to equalize the volumes. To each $0.975 \mathrm{ml}$ test fluid was added $25 \mu \mathrm{l}$ of Pseudomonas suspension containing $8 \times 10^{4} \mathrm{CFU} \mathrm{m}^{-1}$, to give an initial concentration of 2000 viable bacteria $\mathrm{ml}^{-1}$ in each tube. The same bacterial inoculum was also added to a non-bactericidal control tube containing $0.975 \mathrm{ml}$ SWLX. Immediately after mixing, a $25 \mu \mathrm{l}$ sample was removed from this control tube and spread over the surface of a LIB-X agar plate so as to provide a zero-time count of the concentration of viable bacteria in all the tubes. All the tubes were placed in a $15^{\circ} \mathrm{C}$ incubator for $24 \mathrm{~h}$ after which the tubes were shaken and a $25 \mu$ sample removed from each and spread over the surface of a LIB-X agar plate. The plates were held for $2 \mathrm{~d}$ at $20^{\circ} \mathrm{C}$ whereupon the characteristic, jet-black, agar-digesting colonies of Pseudomonas strain No. 111 were large enough to count. A graph was plotted of number of colonies (ordinate) against the logarithm of the reciprocal dilution of the coelomic fluid (abscissa) and a line fitted by eye. The bactericidal titer of the coelomic fluid was taken as the interpolated reciprocal dilution which gave $50 \%$ of the count yielded by the zero-time sample from the SWLX control fluid.

Initial bacterial contamination of coelomic fluid. The same sample of coelomic fluid which was used for determining the bactericidal titer was tested for bacterial contamination by delivering $0.1 \mathrm{ml}$ from the syringe to a LIB-X agar plate. The sample was spread over the surface of the plate which was then incubated for $2 \mathrm{~d}$ at $20^{\circ} \mathrm{C}$ and inspected for colonies.

Statistical analysis. Coelomocyte counts per $\mathrm{ml}$ (for each cell type and for whole coelomic fluid), protein concentration in coelomic fluid and bactericidal titers were analyzed by 2 -way analysis of variance (ANOVA) to test the effect of time and treatment and interaction between these 2 factors.

\section{RESULTS}

\section{Confirmation of paramoebiasis}

All of the echinoids which had been exposed to the infection (except the 8 sacrificed for the presymptomatic group) developed symptoms of paramoebiasis: loss of attachment (LOA) to the aquarium surface, progressive spine loss and tube foot necrosis, gaping peristome, and reddish discoloration of tissues externally and internally. Symptoms first appeared at $10 \mathrm{~d}$ after initial exposure and all 8 of the 72 h post-LOA group had developed their symptoms by Day 15 . The coelomic fluid drawn from infected individuals was reddish in the pre-symptomatic group and colourless, pinkish-brown or greenish-yellow in the $24 \mathrm{~h}$ and $72 \mathrm{~h}$ post-LOA groups. All individuals in the control treatment groups appeared normal externally and internally and the colour of the coelomic fluid varied from pale pink to dark red.

The extent of Paramoeba invadens infection of the samples of radial nerve and associated water vascular canal was variable among the 8 pre-symptomatic individuals exposed to infection. None of these had $P$. invadens in all 5 of the radial nerve samples; 2 individuals had 4 radial nerves infected, 1 had 3 radial nerves infected, 3 had 2 radial nerves infected, 1 had 1 radial nerve infected, and 1 did not yield amoebae from any of the radial nerves cultured. However, $P$. invadens was isolated from all 5 radial nerve samples of all 16 individuals in the infection-treatment $24 \mathrm{~h}$ and $72 \mathrm{~h}$ post-LOA groups. $P$. invadens was not recovered from any radial nerve of any of the 24 individuals in the control-treatment groups.

\section{Coelomocyte quantitation}

After centrifugation, the different coelomocyte types had separated in the discontinuous gradient of sodium metrizoate (Fig. 1A) as shown in Fig. 1B. Band Regions 1 and 3 were consistent in their positions regardless of treatment or sampling time, but Region 2 was qualitatively variable and contained from 0 to 4 thin discrete bands. Microscopic examination showed that Region 1 was predominantly phagocytes, Region 2 was mainly white spherule cells and vibratile cells and Region 3 was almost exclusively red spherule cells. No lysis or morphological abnormalities were observed in any of the cell types except for the loss of motility of the vibratile cells after density-gradient centrifugation. The gradient was fractionated (Fig. 2C) by removing samples with a pipette from the top in such a way that Fraction A $(1.5 \mathrm{ml})$ was the supernate, Fraction B $(1.0 \mathrm{ml})$ contajned Region 1 with the phagocytes, Frac- 
Fig. 2. Strongylocentrotus droebachiensis. Mean number of coelomocytes (cells $\left.\times 10^{6} \mathrm{ml}^{-1}\right)+\mathrm{SE}(n=8)$ for whole coelomic fluid and each of the fractions (Fraction B, phagocytes; Fraction C, white spherule cells; Fraction $D$, red spherule cells) from control (C) and infected (I) echinoids at 3 sampling periods: pre-symptomatic, $24 \mathrm{~h}$ post-LOA and $72 \mathrm{~h}$ post-LOA
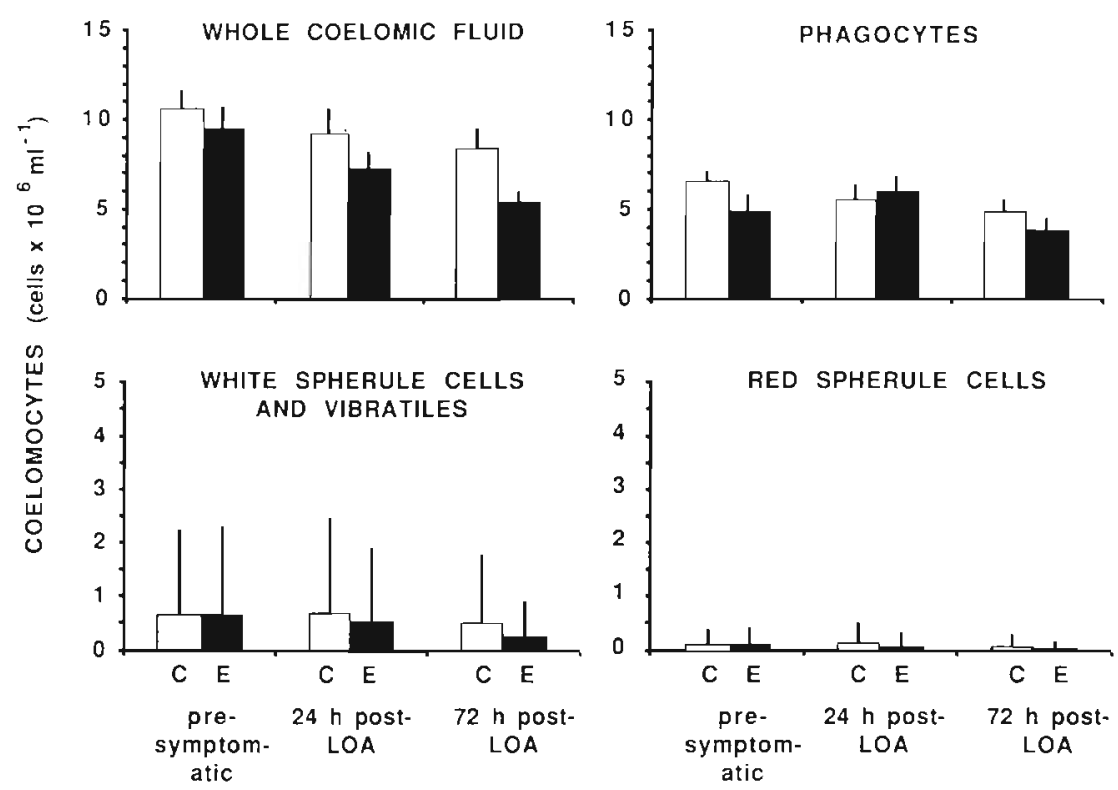

tion C $(2.0 \mathrm{ml})$ comprised Region 2 with the white spherule cells and vibratile cells and Fraction D $(2.0 \mathrm{ml})$ included Region 3 with the red spherule cells. This method provided consistent sampling of Region 2 where the number and exact location of bands was variable. Table 1 presents the coelomocyte counts in whole and fractionated coelomic fluid from 24 healthy echinoids. The average recovery of coelomocytes in the individual fractions was greater than $86 \%$ of the total

Table 1. Strongylocentrotus droebachiensis. Coelomocyte counts (mean and SD) in whole and fractionated coelomic fluid from 24 healthy echinoids

\begin{tabular}{|lcc|}
\hline Fraction & \multicolumn{3}{c|}{$\begin{array}{c}\text { Counts per } \mathrm{ml}\left(\times 10^{-6}\right) \\
\text { Mean }\end{array}$} & $\mathrm{SD}$ \\
\hline Whole CF & 9.48 & 3.31 \\
Supernate & 0.34 & 0.28 \\
Phagocytes & 5.66 & 1.99 \\
White spherule cells \& vibratiles & 1.87 & 0.74 \\
Red spherule cells & 0.31 & 0.19 \\
Sum of all the fractions & 8.18 & - \\
\hline
\end{tabular}

coelomocytes counted in the unfractionated fluids. As mean percentages of the identifiable cell types, phagocytes constituted $72 \%$, vibratiles and white spherule cells $24 \%$ and red spherule cells $4 \%$ (Table 2).

Changes in coelomocyte count during the course of paramoebiasis were investigated by comparing healthy and diseased individuals at the 3 sampling times (Fig. 2). Bartlett's test showed that heterogeneity of variance was non-significant in all analyses except that of red spherule cells, for which the test gave a result that was marginally significant $(p=0.04)$ but no trends of variance were observed. Therefore the data were not transformed for analysis. Analysis of variance of these counts (Table 3 ) showed that the mean total coelomocyte counts were significantly lower $(p<0.025)$ in the infected groups when compared with the controls. There was also a significant decrease $(p<0.025)$ of total coelomocytes over time at $16^{\circ} \mathrm{C}$. These decreases were due primarily to significant decreases associated with infection $(p=0.05)$ and time $(p<0.05)$ in Fraction $C$ which contained white spherule cells and vibratiles, and in the red spherule cells of Fraction $D$, where

Table 2. Strongylocentrotus spp. Percentage of each coelomocyte type (Phag.: phagocytes; Vib: vibratiles; WSC: white sperule cells; RSC: red spherule cells) and total cell counts per ml from coelomic fluid (CF)

\begin{tabular}{|lccccccc|}
\hline Species & \multicolumn{9}{c}{ \% of total CF } & \multicolumn{2}{c|}{ Total cell number } & Source \\
& Phag. & Vib & WSC & RSC & $\left(\times 10^{-6}\right)$ & \\
\hline S. purpuratus & $63-71$ & $13-20$ & $4-6$ & $7-13$ & 8.8 & Yui \& Bayne (1983) \\
S. droebachiensis & $64-70$ & $15-22$ & $3-9$ & $6-10$ & $5-10$ & $\begin{array}{l}\text { Bertheussen \& Seljelid (1978) } \\
\text { S. droebachiensis }\end{array}$ \\
\hline 72 & & 24 & & 4 & 9.5 & This study \\
\hline
\end{tabular}


Table 3. Strongylocentrotus droebachiensis. Two-way analysis of variance of coelomocyte counts (whole and fractionated coelomic fluid)

\begin{tabular}{|llcrcc}
\hline Sample & $\begin{array}{l}\text { Source of } \\
\text { variation }\end{array}$ & df & MS & $F$ & $p$ \\
\hline Phagocytes & Infection & 1 & 6.049 & 1.370 & 0.247 \\
& Time & 2 & 10.241 & 2.332 & 0.110 \\
& Inf. $\times$ Time & 2 & 4.185 & 0.953 & 0.394 \\
& Error & 42 & 4.392 & & \\
White & Infection & 1 & 1.936 & 3.977 & 0.053 \\
spherule & Time & 2 & 3.172 & 6.515 & 0.003 \\
cels and & Inf. $\times$ Time & 2 & 0.798 & 1.640 & 0.206 \\
vibratiles & Error & 42 & 0.487 & & \\
Red sperule & Infection & 1 & 0.090 & 3.230 & 0.079 \\
cells & Time & 2 & 0.138 & 4.940 & 0.012 \\
& Inf. $\times$ Time & 2 & 0.024 & 0.869 & 0.427 \\
Whole & Error & 42 & 0.028 & & \\
coelomic & Infection & 1 & 49.207 & 5.531 & 0.023 \\
fluid & Time & 2 & 42.520 & 4.780 & 0.013 \\
& Inf. $\times$ Time & 2 & 3.587 & 0.403 & 0.671 \\
& Error & 42 & 8.896 & & \\
\hline
\end{tabular}

there was a significant decrease associated with time $(p<0.025)$ but not with infection. No significant differences due to infection or time were observed in Fraction $\mathrm{B}$ containing the phagocytes, and no significant interactions between infection status and time were observed in the whole coelomic fluid or in any of the fractions.

Fraction B (phagocytes) occurred mainly in Channels 8 and 9 of the Coulter Counter; Fraction C (white spherule cells and vibratile cells) registered mainly in Channels 7 and 8 but was represented by 2 distinct peaks. Fraction D (red spherule cells) was detected mainly in Channel 8. From the size range of each channel and the distribution of the coelomocyte types in the particular channels, the approximate size ranges of the various cells ( $\mu \mathrm{m}$ diameter) were calculated to be: phagocytes 16 to 20, white spherule cells 12 to 16 , vibratiles 11 to 13 , and red spherule cells 15 to 17 .

\section{Protein concentrations in coelomic fluid supernates}

Total protein concentrations in the cell-free coelomic fluid were significantly higher in infected individuals than in the controls (Table 4, Fig. 3). Protein concen-

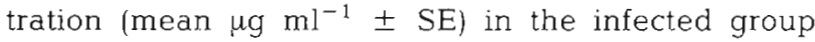
progressively increased from $253.34 \pm 33.55$ in the presymptomatic period (when it was similar to the control group) to $446.25 \pm 51.69$ at $72 \mathrm{~h}$ post-LOA (Fig. 3 ). There was no significant effect of time on protein concentration $(p>0.05)$ although the interaction $(p<0.05)$ of infection and time was significant (Table 3). Protein
Table 4. Strongylocentrotus droebachiensis. Two-way analysis of variance of protein concentration from cell-free coelornic fluid

\begin{tabular}{|llrrrr}
\hline Sample & $\begin{array}{l}\text { Source of } \\
\text { variation }\end{array}$ & df & MD & $F$ & $p$ \\
\hline Protein & Infection & 1 & 152485.362 & 14.047 & 0.001 \\
& Time & 2 & 26420.624 & 2.434 & 0.100 \\
& Inf. $\times$ Time & 2 & 51402.143 & 4.735 & 0.014 \\
& Error & 42 & 10855.591 & & \\
\hline
\end{tabular}

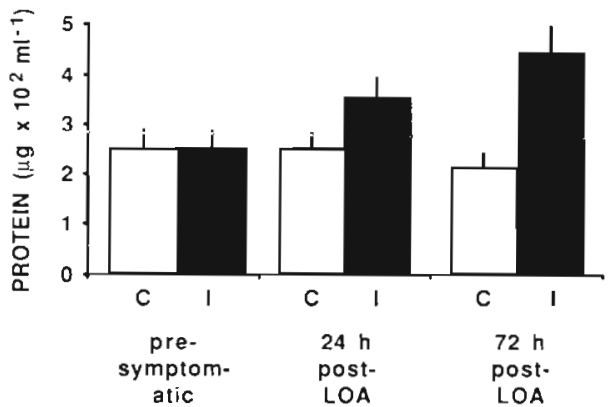

Fig. 3. Strongylocentrotus droebachiensis. Mean total protein $\left(\mu \mathrm{g} \times 10^{2} \mathrm{ml}^{-1}\right)+\mathrm{SE}(n=8)$ in cell-free coelomic fluid from control (C) and infected (I) echinoids at 3 sampling periods:

pre-symptomatic, $24 \mathrm{~h}$ post-LOA and $72 \mathrm{~h}$ post-LOA

concentration in the control groups showed little variation: the overall mean $\pm \mathrm{SE}(n=24)$ was $238.56 \pm$ 16.60 $\mu \mathrm{g} \mathrm{ml}^{-1}$ (Fig. 3).

\section{Bactericidal titer of coelomic fluid}

Fig. 4 shows mean \pm SE bactericidal titers for infected and control groups at pre-symptomatic, $24 \mathrm{~h}$ post-LOA and $72 \mathrm{~h}$ post-LOA. Eighteen was the high-

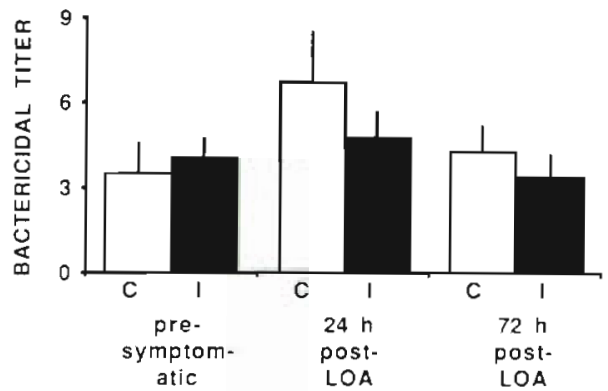

Fig. 4. Strongylocentrotus droebachiensis. Mean bactericidal titers of cell-free coelomic fluid from control (C) and infected (I) echinoids at 3 sampling periods: pre-symptomatic, $24 \mathrm{~h}$ post-LOA and $72 \mathrm{~h}$ post-LOA $(n=8)$ 
est titer recorded (control, $24 \mathrm{~h}$ post-LOA) in any of the 48 echinoids tested in the experiment. At the other end of the activity spectrum, there were 2 echinoids (control, pre-symptomatic and infected, $72 \mathrm{~h}$ post-LOA) whose coelomic fluid, even when undiluted, failed to reduce the added CFU to $50 \%$ of its initial value. The titers of these fluids were recorded as 0.1 for statistical analysis. The end-point of 1 sample (control, pre-symptomatic) was $>8$ but was not determined; a value of 10 was extrapolated from the data for statistical analysis. There was no significant effect of time or infection on bactericidal titer, nor was there any significant interaction between these 2 factors ( 2 -way ANOVA, $p>0.05$ ). Moribund individuals, however, had a high incidence of heavily contaminated (defined as $>200 \mathrm{CFU} \mathrm{m}^{-1}$ ) coelomic fluid, especially in the terminal stages of the disease $(2$ and 5 out of 8 individuals showed heavy bacterial contamination at $24 \mathrm{~h}$ and $72 \mathrm{~h}$ post-LOA respectively). Even this heavy contamination did not obscure the results of the bactericidal tests, since the agar-digesting, black-colonied Pseudomonas 111 was readily distinguished from the contaminants, most of which had white colonies and did not attack agar.

\section{Toxicity studies}

There were no symptoms of paramoebiasis in any individuals within $30 \mathrm{~d}$ after injection with either experimental or control CF filtrate. All echinoids in both groups subsequently developed symptoms of paramoebiasis (LOA) 10 to $12 \mathrm{~d}$ after exposure to diseased conspecifics, and the disease followed the usual time course to mortality in both groups.

\section{DISCUSSION}

This study has confirmed the reproducibility and utility of the waterborne infection apparatus originally designed by Scheibling \& Stephenson (1984) for transmission of sea-urchin paramoebiasis from field-collected, diseased specimens to healthy individuals. This equipment was further used by Jones \& Scheibling (1985) to demonstrate the transmission of the waterborne agent of the disease, Paramoeba invadens (Jones 1985) from injected echinoids to healthy specimens. This apparatus provides controlled and continuous exposure to the disease and ensures the development of symptoms (as evidenced by LOA) at a remarkably constant interval from the start of exposure. In the present study, LOA and progressive development of paramoebiasis symptoms occurred after $10 \mathrm{~d}$ of exposure to infected individuals at $16^{\circ} \mathrm{C}$. This was in close agreement with the results of Scheibling \& Stephen- son's (1984) study (50\% morbidity at 9.5 to $11.5 \mathrm{~d}$ ), despite slight differences in the flow rates, in the number and size of echinoids at the disease source, and in the volume and material of the tubes which contained these diseased echinoids. $P$. invadens has been consistently isolated from radial nerve/ambulacral canal samples of symptomatic echinoids (Jones \& Scheibling 1985, Jellett 1988). This study indicates that amoebae are present in at least some of the radial nerves well before the onset of visible symptoms.

The clumping or clotting of coelomocytes in withdrawn coelomic fluid is known to be calcium-dependent (Kanugo 1982, Henson \& Schatten 1983) and calcium-chelating agents such as EDTA (ethylenediaminetetra-acetic acid) (Kanugo 1982) and EGTA (Bertheussen \& Seljelid 1978, Messer \& Wardlaw 1980, Edds et al. 1983) have been used to prevent cellular coagulation. In this study, EGTA (H\&S anticoagulant) was found to be satisfactory for preventing clotting and maintaining the even suspension of coelomocytes which was necessary for density-gradient separation and for Coulter counting. Cell suspensions in $\mathrm{H} \& \mathrm{~S}$ anticoagulant exhibited normal morphology in phase contrast and differential interference contrast microscopy, and no lysis was observed. This is consistent with previous use of EGTA for this purpose (Bertheussen \& Seljelid 1978, Messer \& Wardlaw 1980. Edds et al. 1983) and indicates that calcium-chelation does not produce significant morphological changes in coelomocytes, at least during exposure of up to $2 \mathrm{~h}$.

The discontinuous gradient of sodium metrizoate permitted a similar separation of coelomocytes to that found by Bertheussen \& Seljelid (1978). In this study, an increased steepness of the density gradient in the central band area gave a greater separation of the white sperule cells and the vibratile cells. However, separation was still insufficient for the satisfactory removal of the 2 cell types as distinct fractions. For this reason, we decided to pool these 2 types of cells to ensure consistency of fractionation of fluids from different individuals. Direct comparison of the gradient method used here with that of Bertheussen \& Seljelid (1978) is limited by lack of information on the composition of the 'pure metrizoate' used in the cushion fluid by the latter authors.

Previous reports, together with the data presented here (Table 2), of total coelomocyte counts and percentages of individual coelomocyte types show consistency between different investigators and species of echinoid. Kanugo (1982) found $1.04 \times 10^{7} \mathrm{ml}^{-1}$ coelomocytes in the sea star Asterias forbesi, which is also similar to that found in echinoids (Table 2). Our results confirm both the utility of the density-gradient method for fractionation of coelomocytes and of the Coulter Counter for rapid and accurate counting. In our 
work, cell sizes calculated from those Coulter Counter channel peaks where the majority of each cell type occurred were in good agreement with previous reports (Bertheussen \& Seljelid 1978, Smith 1981), with the exception of vibratiles which were somewhat larger in this study $(12 \mu \mathrm{m}$ as compared with 5 to $10 \mu \mathrm{m})$. This size discrepancy may be due to differences in technique of measurement, or to a swelling effect of the $\mathrm{H} \& \mathrm{~S}$ anticoagulant, or to the metrizoate gradient material.

Coelomocyte numbers are known to decrease with bacterial infection. Messer \& Wardlaw (1980) found that Echinus esculentus injected with $10^{9} \mathrm{CFU}$ of bacteria showed a general decline in all coelomocyte bands. Yul \& Bayne (1983) noted an overall drop in coelomocyte numbers of Strongylocentrotus purpuratus from $8.8 \times 10^{6}$ to $6 \times 10^{5} \mathrm{ml}^{-1}$ after injection of Gram-negative bacteria, with a decrease in the relative proportion of phagocytes and red spherule cells, an increase in the percentage of vibratiles and no change in the percentage of white spherule cells. In contrast, $S$. droebachiensis infected by the protozoan $P$. invadens showed no change in the numbers of phagocytes. and the decrease in total coelomocyte count was due mainly to a decline in the numbers of white spherule and vibratile cells. This may be an indication of differences in coelomocyte response to bacteria as compared with a moebae. The constancy of phagocyte numbers in the coelomic fluid almost to the time of death indicates either a failure of these cells to recognize the amoebae as foreign, or a replacement of phagocytes that exactly compensates for disappearances from the coelomic fluid.

The decrease in coelomocyte number over time at $16^{\circ} \mathrm{C}$ indicates that prolonged periods of relatively high temperature may be stressful to Strongylocentrotus droebachiensis and may be a predisposing factor for paramoebiasis. Previous work has demonstrated a link between high temperature and paramoebiasis in this species (Scheibling \& Stephenson 1984), and Jellett (1988) has shown that growth rate of Paramoeba invadens in vitro is highest between 15 and $20^{\circ} \mathrm{C}$. These 2 temperature effects could act in concert to produce symptomatic paramoebiasis in echinoids. Whether asymptomatic infection occurs at lower temperatures remains to be determined.

The concentration of protein (mean $\pm S E$ ) found in normal coelomic fluid of Strongylocentrotus droebachiensis in this study was $238.56 \pm 16.60$ $\mu \mathrm{g} \mathrm{ml} \mathrm{m}^{-1}$, which is somewhat higher than that previously reported ( 65 to $180 \mathrm{ug} \mathrm{ml}^{-1}$ ) by Bertheussen \& Seljelid (1978). Total protein concentration in coelomic fluid from echinoids with advanced paramoebiasis was elevated approximately 2 -fold. The additional protein probably is not an amoebic toxin or lytic enzyme, since healthy echinoids injected with cell-free coelomic fluid from infected conspecifics showed no symptoms of disease. However, this possibility cannot be ruled out as the amount of material injected may not have been sufficient to generate symptoms, or the active compound may have been denatured by freezing. The extra protein may be a humoral immunity factor (released by the coelomocytes or other cells in response to amoebic infection) similar to the interleukin-1-like protein found in the coelomic fluid of Asterias forbesi (Beck \& Habicht 1986), although it did not confer resistance to paramoebiasis in echinoids injected with it, nor did it slow the progression of the disease. Another possibility is that the increased protein in Paramoebainfected echinoid coelomic fluid is due to tissue or coelomic cell lysis during the progression of the disease (see Jones et al. 1985), but an increase in cellular debris was not observed in the supernatant fraction of the coelomic fluid on the density gradients. Yet another possibility is that the elevated protein level is the result of amoeba-induced autolytic enzyme secretion by the echinoid cells, a phenomenon which could cause the histopathological damage observed in paramoebiasis (Jones et al. 1985). Further work is needed to quantify and characterize particular protein or proteins which account for the elevated protein values in coelomic fluid of diseased echinoids.

The bactericidal activity of the whole coelomic fluid against a marine pseudomonad was not impaired over time at $16^{\circ} \mathrm{C}$ or by the presence or progression of the paramoebiasis infection. Although prolonged high temperature results in a decrease in the number of coelomocytes which may result in a diminished immune capability, the specific antibacterial activity of the fluid was not likewise effected. Within the groups of 8 echinoids, there was considerable between-individual variation both in bactericidal titer of the coelomic fluids towards Pseudomonas 111 and in the incidence of echinoids with bacterially contaminated $C F$. The dramatic effect of the infection on the neuromuscular system of the echinoid that causes LOA seems to have no significant impact on the bactericidal titer towards Pseudomonas 111. Thus, even moribund $72 \mathrm{~h}$ post-LOA specimens still had average bactericidal titers similar to those of healthy specimens. Most of the $72 \mathrm{~h}$ post-LOA Paramoeba-infected echinoids had heavily contaminated CF (bacterial types immune to the antibacterial activity), 5 out of 8 having $>10^{4} \mathrm{CFU}$ $\mathrm{ml}^{-1}$. Thus it was common for the echinoids to have a terminal bacteremia, but this came after the LOA and did not cause it. How the amoebae elude the defence mechanisms of the echinoids is not known, but these results are an indication that the presence of the amoebae did not result in a general loss of antimicrobial activity. 
Acknowledgements. This research was funded by a Natural Sciences and Engineering Research Council Strategic grant to R.E.S., and was done while one of the authors (A.C.W.) was a visiting scientist supported by the Atlantic Institute of Biotechnology, the Marshall and Orr Fund of the Royal Society, and the Carnegie Trust. The authors wish to thank the following: Dr Jim Novitsky for use of equipment, Dalhousie University Department of Oceanography for use of the Coulter Counter, and Catherine Ellis, Andrea Griswold and Bruce Raymond for excellent technical assistance.

\section{LITERATURE CITED}

Baross, J. A., Hanus, F. J., Morita, R. Y. (1974). Effects of hydrostatic pressure on uracil uptake, ribonucleic acid synthesis, and growth of three obligately psychrophilic marine fibrios, Vibrio alginolyticus, and Escherichia coli. In: Colwell, R. R., Morita, R. Y (eds.) Effects of the ocean environment on microbial activities. University Park Press, Baltimore, p. 180-202

Beck, G., Habicht, G. S. (1986). Isolation and characterization of a primitive interleuken-1-like protein from an invertebrate, Asterias forbesi. Proc natl Acad. Sci. U.S.A. 83: $7429-7433$

Bertheussen, K., Seljelid, R. (1978). Echinoid phagocytes in vitro. Expl Cell Res. 111: 401-412

Edds, K. T., Chambers, C., Allen, R. D. (1983). Coelomocyte motility. Cell Motility 1: 113-121

Henson, J. H., Schatten, G. (1983). Calcium regulation of the actin-mediated cytoskeletal transformation of sea urchin coelomocytes. Cell Motility 3: 525-534

Jellett, J. F. (1988). Host-pathogen interactions in sea urchin disease. Ph. D thesis, Dalhousie University, Halifax

Jones, G. M. (1985). Paramoeba invadens n. sp. (Amoebida, Paramoebidae), a pathogenic amoeba from the sea urchin, Strongylocentrotus droebachiensis, in Eastern Canada. J. Protozool. 32: 364-369

Jones, G. M., Scheibling, R. E. (1985). Paramoeba sp. (Amoebida, Paramoebidae) as the possible causative agent of sea urchin mass mortality in Nova Scotia. J. Parasitol. 71: $559-565$

Jones, G. M., Hebda, A. J., Scheibling, R. E., Miller, R. J.
(1985). Histopathology of the disease causing mass mortality of sea urchins (Strongylocentrotus droebachiensis) in Nova Scotia. J. Invert. Pathol 45: 260-271

Kanugo, K. (1982). In vitro studies on the effects of cell-free coelomic fluid, calcium, and/or magnesium on clumping of the coelomocytes of the sea star Asterias forbesi (Echinodermata: Asteroidea). Biol. Bull. mar biol. hab., Woods Hole 163: 438-452

Messer, L. I., Wardlaw, A. C. (1980). Separation of the coelomocytes of Echinus esculentus by density gradient centrifugation. Proc. Eur Colloq. Echinoderms, Brussels. In: Jangoux, M. (ed.) Echinoderms present and past. A. A Balkema, Rotterdam, p. 319-323

Miller, R. J. (1985). Succession in sea-urchin and seaweed abundance in Nova Scotia, Canada. Mar. Biol. 84: 275-286

Miller, R. J., Colodey, A. G. (1983). Widespread mass mortalities of the green sea urchin in Nova Scotia, Canada. Mar. Biol. 73: 263-267

Scheibling, R. E. (1984). Echinoids, epizootics and ecological stability in the rocky subtidal off Nova Scotia, Canada. Helgoländer Meeresunters. 37: 233-242

Scheibling, R. E. (1986). Increased macroalgal abundance following mass mortalities of sea urchins (Strongylocentrotus droebachiensis) along the Atlantic coast of Nova Scotia. Oecologia (Berl.) 68: 186-198

Scheibling, R. E., Stephenson, R. L. (1984). Mass mortality of Strongylocentrotus droebachiensis (Echinodermata: Echinoidea) off Nova Scotia, Canada. Mar Biol. 78: 153-164

Smith, V J. (1981). The Echinoderms. In: Ratcliffe, N. A., Rowley, A. F. (eds.) Invertebrate blood cells, Vol. 2. Academic Press, New York, p. 514-548

Wardlaw, A. C., Messer, L. I. (1982). Bactericidal activity of coelomic fluid from the sea urchin. In: Primrose, S. B., Wardlaw, A. C. (eds.) Sourcebook of experiments for the teaching of microbiology. Academic Press, New York, p. $555-560$

Wardlaw, A. C., Unkles, S. E. (1978). Bactericidal activity of coelomic fluid from the sea urchin Echinus esculentus. J. Invert. Pathol. 32: 25-34

Yui, M. A., Bayne, C. J. (1983). Echinoderm immunology: bacterial clearance by the sea urchin Strongylocentrotus purpuratus. Biol. Bull. mar. biol. Lab., Woods Hole 165: $473-486$ 